\title{
Assessment of Genetic Relationships among Philodendron Cultivars Using AFLP Markers
}

\author{
Pachanoor S. Devanand ${ }^{1}$ \\ Department of Botany and Plant Sciences, University of California-Riverside, Riverside, \\ CA 92521-0124
}

Jianjun Chen 2,5 and Richard J. Henny
Mid-Florida Research and Education Center and Environmental Horticultural Department, IFAS,
University of Florida, 2725 Binion Road, Apopka, FL 32703-8504

Chih-Cheng T. Chao,, 5

Department of Botany and Plant Sciences, University of California-Riverside, Riverside, CA 92521-0124

\begin{abstract}
AdDitional INDEX WORDs. amplified fragment length polymorphism markers, Araceae, aroid, interspecific hybrids, philodendrons, tropical ornamental foliage plants

Abstract. Philodendrons (Philodendron Schott) are among the most popular tropical ornamental foliage plants used for interior decoration. However, limited information is available on the genetic relationships among popular Philodendron species and cultivars. This study analyzed genetic similarity of 43 cultivars across 15 species using amplified fragment length polymorphism (AFLP) markers with near infrared fluorescence labeled primers. Forty-eight EcoR I + 2 / Mse I + 3 primer set combinations were screened, from which six primer sets were selected and used in this investigation. Each selected primer set generated 96 to 130 scorable fragments. A total of 664 AFLP fragments were detected, of which $424(64 \%)$ were polymorphic. All cultivars were clearly differentiated by their AFLP fingerprints, and the relationships were analyzed using the unweighted pair-group method of arithmetic average cluster analysis (UPGMA) and principal coordinated analysis (PCA). The 43 cultivars were divided into five clusters. Cluster I comprises eight cultivars with arborescent growth style. Cluster II has only one cultivar, 'Goeldii'. There are $\mathbf{1 6}$ cultivars in cluster III, and most of them are self-heading interspecific hybrids originated from R.H. McColley's breeding program in Apopka, Fla. Cluster IV contains 13 cultivars that exhibit semi-vining growth style. Cluster $\mathbf{V}$ has five cultivars that are true vining in morphology, and they have lowest genetic similarity with philodendrons in other clusters. Cultivated philodendrons are generally genetically diverse except the self-heading hybrids in cluster III that were mainly developed using self-heading and semi-vining species as parents. Seven hybrid cultivars have Jaccard's similarity coefficients of 0.88 or higher, suggesting that future hybrid development needs to select parents with diverse genetic backgrounds.
\end{abstract}

The genus Philodendron contains more than 700 species (Croat, 1997), making it the second largest genus in the family Araceae (also referred to as aroids). Philodendrons are native to tropical America and comprise a conspicuous component of the native flora. All Philodendron species are open-pollinated as the flowers are unisexual in nature (Mayo et al., 1997). However, species differ widely in growth habits from climbing to arborescent, leaf sizes vary from small $(10 \mathrm{~cm}$ long and $6 \mathrm{~cm}$ wide) to gigantic $(120 \mathrm{~cm}$ long and $40 \mathrm{~cm}$ wide), leaf shapes from heartleaf to palm-like, and leaf colors from light yellow to burgundy (Croat, 1997; Grayum, 1996; Mayo, 1991). Thus, many philodendrons have been grown

Received for publication 29 Nov. 2003. Accepted for publication 27 Feb. 2004. The authors thank Agri-Starts II, Inc. and Twyford International Inc., Apopka, Fla., and the Botanical Garden of the Univ. of California-Riverside for providing Philodendron cultivars used in this study; Russell D. Caldwell for collecting the plant samples in Florida, and Kelly Everitt for critical reading of this manuscript. This research was supported in part by the California Agricultural Experiment Station, Univ. of California Cooperative Extension, and Florida Agricultural Experiment Station.

'Postdoctoral Scholar.

${ }^{2}$ Assistant Professor.

3Professor.

${ }^{4}$ Assistant Cooperative Extension Specialist and Assistant Horticulturist.

${ }^{5}$ Co-corresponding authors: J. Chen, phone: 407-884-2034 x161, email: jjchen@mail.ifas.ufl.edu or C.T. Chao, phone: 909-787-3441, email: ctchao@citrus.ucr.edu as ornamental foliage plants (Huxley, 1994; Liberty Hyde Bailey Hortorum, 1976). In fact, Philodendron formerly dominated all other genera of tropical ornamental foliage plants, accounting for $50 \%$ and $36 \%$ of the national wholesale value of foliage plants in the United States in 1956 and 1967, respectively (Chen et al., 2002; McConnell et al., 1989). Based on their growth habits, philodendrons were divided into three groups by McColley and Miller (1965). The first group is the vining or scandent, such as $P$. scandens K. Koch \& Sello (heartleaf philodendron); it is grown as either hanging baskets or containerized plants where vines are supported by totem poles. The second group has a selfheading and upright growing style, which is represented by $P$. wendlandii Schott. The third group is the erect-arborescent type, such as P. bipinnatifidum Endl., which appear self-heading when they are young, but assume more woody and treelike shapes as they are mature.

Documented hybridization within the genus Philodendron dates from 1887 in Florence, Italy (Wilfret and Sheehan, 1981). The first U.S. hybrid was developed by Manda in 1936 from the cross between P. hastatum C. Koch \& H. Sello (now considered to be $P$. domesticum Bunt.) and P. erubescens K. Koch $\&$ Augustin (Bald, 1951). Since then, outstanding self-heading Philodendron hybrids with red, yellowish, or orange foliages have been released from R.H. McColley's breeding program at Bamboo Nursery in Apopka, Fla. (Norris, 1987). McColley and 
Miller (1965) claimed that crosses of plants between either group could not be successful. Henny and Chen (2003) explained this might be due to the differences in chromosome numbers since $2 n=32,34$, and 36 were found in $P$. scandens, $P$. wendlandii, and $P$. bipinnatifidum, respectively.

Despite their importance as ornamental foliage plants, genetic relationships among Philodendron cultivars have not been determined. Amplified fragment length polymorphism (AFLP) is a PCR-based assay for plant DNA fingerprinting that reveals significant levels of DNA polymorphism (Vos et al., 1995). Molecular marker profiles based on AFLPs can be used to detect variation at the DNA level and have proven to be extremely effective in distinguishing closely related genotypes. Other advantages of this technique include reproducibility, high resolution, genome-wide distribution of markers, and no required prior knowledge of the genome being studied (Mueller and Wolfenbarger, 1999). The objectives of this study were to determine genetic relationships of common cultivars of Philodendron and to provide a genetic basis for future attempts in hybrid development and for conservation of Philodendron genetic resources.

\section{Materials and Methods}

Plant materials. Forty-three Philodendron cultivars along with one cultivar each of five other ornamental foliage aroid genera [Aglaonema Schott, Alocasia (Schott) G. Don, Anthurium Schott, Dieffenbachia Schott, and Spathiphyllum Schott] were collected from the research greenhouses at the Univ. of Florida's Mid-Florida Research and Education Center(MREC), ornamental foliage plant nurseries in central Florida, and the Botanical Garden at the Univ. of California-Riverside (UCRBG) (Table 1).

FLuORESCENT-AFLP ANALYSIS. AFLP analysis was performed based on Chen et al. (2004a). Briefly, total DNA was extracted from young leaves using the DNeasy system (Qiagen, Valencia, Calif.). AFLP analysis was conducted using the GIBCO BRL AFLP System II (Life Technologies, Grand Island, N.Y.) and visualized with the LI-COR IR automated sequencer 4000-L(LICOR, Lincoln, Nebr.). Total DNA (125 ng) from all samples was digested with $1 \mathrm{ml}$ of mixture of EcoR I/Mse I (1.25 units/ $\mu \mathrm{L})$ at $37^{\circ} \mathrm{C}$ overnight and ligated to $E c o R$ I/Mse I adapters with 1.5 $\mu \mathrm{L}(1 \mathrm{unit} / \mu \mathrm{L})$ of T4 DNA ligase at $25^{\circ} \mathrm{C}$ for at least $6 \mathrm{~h}$. Preamplification reactions were performed on a MJR Cycle LR (MJ Research, Watertown, Mass.). The pre-amplified PCR product was quantified in the fluorometer, and the amount of template for subsequent PCR was diluted to $125 \mathrm{ng} \cdot \mu \mathrm{L}^{-1}$, and selective amplification was performed.

The selective amplification PCRs was performed by another touchdown program as described by Chen et al. (2004a). Both pre- and selective-amplification conditions were modified according to Myburg et al. (2000). The products from the selective amplification were electrophoresed on $25 \mathrm{~cm} \times 0.25 \mathrm{~mm} 8 \%$ denaturing polyacrylamide Long Ranger Gel Solution (BMA, Rockland, Maine) in $0.8 \times$ TBE buffer using a LI-COR automated sequencer 4000-L.

Initially, a total of 48 AFLP primers were screened, from which six primer sets (IRD700 E+TC/M+CAA; IRD800 E+AA/ M+CAA; IRD700 E+TC/M+CAT; IRD800 E+AA/M+CAT; IRD700 E+GG/M+CAA; and IRD800 E+CC/M+CAA) that showed clear scorable and highly polymorphic fragments (Table 2) were selected for fluorescent-AFLP reactions with the samples of the 43 Philodendron cultivars and five aroid genera listed in Table 1 .
Data Analysis. AFLP fragments were visually scored as present (1) or absent (0) to create the binary data set. The data was entered into a binary data matrix as discrete variables. Jaccard's coefficient of similarity (Sneath and Sokal, 1973) was calculated for all pair-wise comparisons among the 43 Philodendron cultivars and 5 other aroid genera as follows: Jaccard $=\mathrm{NAB} /\left(\mathrm{N}_{\mathrm{AB}}+\mathrm{N}_{\mathrm{A}}\right.$ $+N_{B}$ ), where $N_{A B}$ is the number of bands shared by two cultivars (A and $\mathrm{B}$ ); $\mathrm{N}_{\mathrm{A}}$ represents amplified fragments in cultivar A only and NB represents fragments in cultivar B only. A dendrogram was generated by cluster analysis using the unweighted pair group method of the arithmetic averages (UPGMA). Principal coordinated analysis (PCA) was also carried out to show multiple dimensional distributions of the cultivars in a scatter-plot (NTSYS-pc, version 2.1) (Rohlf, 2000).

\section{Results and Discussion}

AFLP PROFILES AND ANALYsis. Clear-cut AFLP profiles were generated by the six primer sets for the 43 philodendron cultivars and five other aroid genera, and each primer set generated identical fragment patterns for the duplicated cultivar 'Moonlight' (the duplicates came from separate DNA preparations). An example of fluorescent-AFLP profile of 30 Philodendron cultivars with one duplicated 'Moonlight' and five other aroid genera is shown in Fig. 1. Using the six selected primer combinations, a total of 664 scorable AFLP fragments were generated, of which 424 (64\%) were polymorphic (Table 2). The fragments ranged from 50 to $650 \mathrm{bp}$ with a majority of the polymorphism being distributed between 150 and $350 \mathrm{bp}$. On average, each primer set produced 110.7 fragments with 70.7 fragments being polymorphic. The level of polymorphism from this study is similar to that detected in other plants when AFLP techniques were used for measuring genetic variability. Aggarwal et al. (2002) identified 501 AFLP markers from basmati rice (Oryza sativa L.) with $65 \%$ of them being polymorphic. Chen et al. (2004a, 2004b) reported $69 \%$ polymorphism in Aglaonema and $71 \%$ polymorphism in Dieffenbachia, two other aroid genera.

Genetic Relationships AMONG Cultivars. A dendrogram for the Philodendron cultivars and five other aroid genera was constructed based on the UPGMA analysis using Jaccard's coefficients of similarity (Fig. 2). The 43 cultivars are divided into five clusters. Clusters I, III, IV, and V contain arborescent, self-heading, semi-vining, and vining-type cultivars, respectively, whereas cluster II has only one cultivar 'Goeldii' whose stem is erect or hanging, sometimes tortuous.

Jaccard's similarity coefficients for cultivars in cluster I range from 0.48 to 0.70 . 'Selloum' is a $P$. bipinnatifidum (formerly $P$. selloum C. Koch) and grown as a freestanding specimen in many container sizes and ultimately becoming woody and fairly erect. 'Selloum' is also grown in tropical or subtropical regions under shade as a landscape plant, and may spread to more than $3 \mathrm{~m}$ across. Generally, P. bipinnatifidum, native to Brazil, is hardy and able to tolerate a temperature close to freezing (Griffith, 1998). 'Xanadu' is a miniature form of 'Selloum' with a more compact appearance. 'Classic Xanadu', as its name indicates, resembles 'Xanadu'. 'Showboat' is a sport of 'Xanadu'. 'Hope' is selected from a self pollination of 'Selloum' and is more of a dwarf cultivar. 'Baby Hope' is a somaclonal variant of 'Hope'. The origin of 'Octopus' is unknown; it may also come from the same cross as 'Hope'. 'Williamii' is a $P$. williamsii Hook. Like 'Selloum', it is arborescent and native to Brazil.

All cultivars in the cluster I belong to $P$. bipinnatifidum except 
Table 1. Backgrounds, growth habits, origins, and sources of 43 Philodendron cultivars and five aroid controls used in this study.

\begin{tabular}{|c|c|c|c|c|}
\hline Cultivars & Background & Growth habit & Origin & Sources \\
\hline $101-1$ & Hybrid & Self-heading & Florida & UF/MRECz \\
\hline $102-4$ & Hybrid & Self-heading & Florida & UF/MREC \\
\hline $103-2$ & Hybrid & Self-heading & Florida & UF/MREC \\
\hline $104-3$ & Hybrid & Self-heading & Florida & UF/MREC \\
\hline Angus ectifolium & P. angustisectum & Semi-vining & Colombia & Twyford, Inc. ${ }^{y}$ \\
\hline Autumn & Hybrid & Self-heading & Florida & UF/MREC \\
\hline Baby Hope & Variant of 'Hope' & Arborescent & Florida & UF/MREC \\
\hline Banda Birdnest Philly & Unknown & Vining & Unknown & Agri-Starts, Inc. ${ }^{x}$ \\
\hline Bituec & Hybrid & Self-heading & Florida & Agri-Starts, Inc \\
\hline Black Cardinal & Hybrid & Self-heading & Florida & UF/MREC \\
\hline Burke Marx & P. imbe & Semi-vining & Brazil & Agri-Starts, Inc. \\
\hline Classic Xanadu & P. bipinnatifolium Endl. & Arborescent & Unknown & UF/MREC \\
\hline Ginny & Unknown & Vining & Unknown & Agri-Starts, Inc. \\
\hline Goeldii & P. goeldii & Goeldii type & French Guyana & Twyford, Inc \\
\hline Greg Hambeli 1 & Unknown & Semi-vining & Unknown & Twyford, Inc. \\
\hline Greg Hambeli 2 & Unknown & Semi-vining & Unknown & Twyford, Inc. \\
\hline Greg Hambeli Sq Petiole & Unknown & Semi-vining & Unknown & Twyford, Inc. \\
\hline Hope & Selfed $P$. bipinnatifolium & Self-heading & Florida & Twyford, Inc \\
\hline Hybrid Selloum & Unknown & Semi-vining & Unknown & Twyford, Inc. \\
\hline Imperial Green & Hybrid & Self-heading & Florida & Twyford, Inc. \\
\hline Imperial Red & Hybrid & Self-heading & Florida & Twyford, Inc \\
\hline Imperial Red Philo. & Hybrid & Self-heading & Florida & UCRBGw \\
\hline Lime Tetraploid & Unknown & Self-heading & Unknown & UF/MREC \\
\hline Moonlight & Hybrid & Self-heading & Florida & UF/MREC \\
\hline Octopus & Unknown & Arborescent & Unknown & Twyford, Inc \\
\hline Panda & P. bipennifolium & Semi-vining & Brazil & Agri-Starts, Inc. \\
\hline Pertusum & Unknown & Vining & Unknown & Agri-Starts, Inc. \\
\hline Pinnatifidum & P. pinnatifidum & Semi-vining & Venezuela & Agri-Starts, Inc. \\
\hline Pinnatifidum & P. pinnatifidum & Semi-vining & Venezuela & UCRBG \\
\hline Princess of Orange & Hybrid & Self-heading & Florida & UF/MREC \\
\hline Red Bristle & P. pedatum Kunth \& Bouche & Semi-vining & Venezuela to Brazil & Agri-Starts, Inc \\
\hline Royal Queen & Hybrid & Self-heading & Florida & Agri-Starts, Inc. \\
\hline Rudolph & Unknown & Semi-vining & Unknown & Twyford, Inc. \\
\hline Sawtooth & Unknown & Self-heading & Unknown & Twyford, Inc. \\
\hline Scandent & P. scandens & Vining & Mexico to Brazil & UF/MREC \\
\hline Selloum & P. bipinnatifolium & Arborescent & Brazil & UF/MREC \\
\hline Showboat & Sport of 'Xanadu' & Arborescent & Unknown & Twyford, Inc. \\
\hline Sunset & Hybrid & Self-heading & Florida & UF/MREC \\
\hline Sunshine & Unknown & Semi-vining & Unknown & UCRBG \\
\hline Tahiti Green & Unknown & Semi-vining & Unknown & Twyford, Inc. \\
\hline Variegated Scandent & Sport of 'Scandent' & Vining & Unknown & Twyford \\
\hline Williamii & P. williamsii & Arborescent & Brazil & Agri-Starts, Inc \\
\hline Xanadu & P. bipinnatifolium & Arborescent & Unknown & UF/MREC \\
\hline \multirow[t]{2}{*}{ Amazonica } & Alocasia lowii Hook.f. $\mathrm{x}$ & & & \\
\hline & A. sanderiana Bull. & $\mathrm{NA}^{\mathrm{v}}$ & Unknown & Agri-Starts, Inc. \\
\hline Red Hot & Anthurium $\times$ & NA & Florida & UF/MREC \\
\hline Treubii & Aglaonema commutatum Schott & NA & The Philippines & UF/MREC \\
\hline \multirow[t]{2}{*}{ Compacta } & Dieffenbachia maculata & & & \\
\hline & (Lodd.) G. Don. & NA & Unknown & UF/MREC \\
\hline 64706 & Spathiphyllum $\times$ & NA & Unknown & UF/MREC \\
\hline
\end{tabular}

zUniv. of Florida, Mid-Florida Research and Education Center, Apopka.

yTwyford International, Inc. Apopka, Fla.

${ }^{x}$ Agri-Starts II, Inc. Apopka, Fla.

wUniv. of California-Riverside Botanic Garden, Riverside, Calif.

vNot applicable as they are other aroids as controls. 


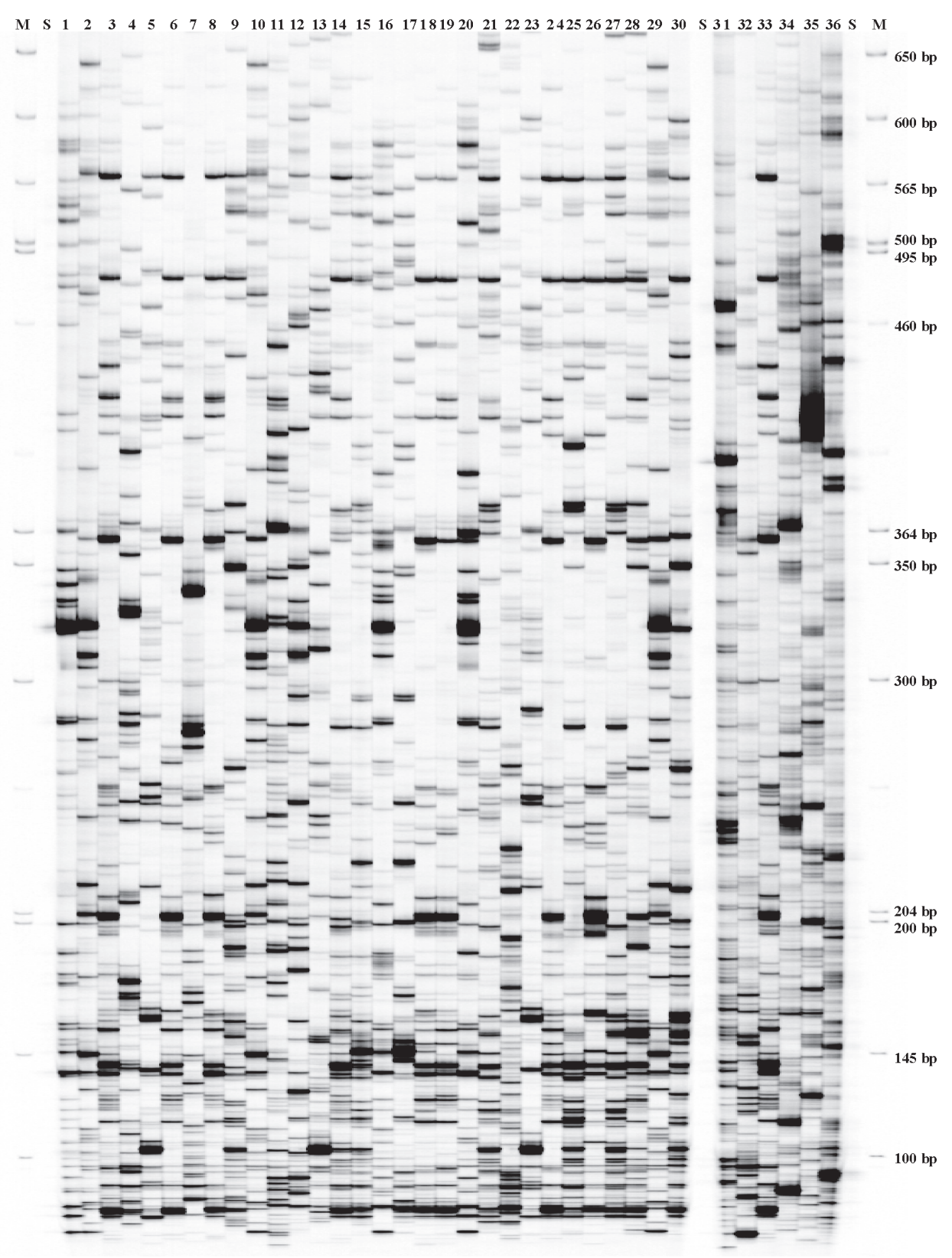

Fig. 1. Fluorescent-AFLP profiles of 30 Philodendron cultivars, one duplicated 'Moonlight' control, and five other aroid genera controls using primer IRD700 E+GG/ M+CAA. The samples are arranged from left to the right in the order of (M) size markers, (S) space, (1) 'Selloum', (2) 'Xanadu', (3) 'Moonlight', (4) 'Scandent', (5) 'Angus ectifolium', (6) ‘Autumn', (7) 'Banda Birdnest Philly', (8) ‘Bituec', (9) 'Burke Marx', (10) 'Classic Xanadu', (11) 'Ginny', (12) 'Goeldii', (13) ‘Greg Hambeli Square Petiole', (14) ‘Greg Hambeli \#1', (15) 'Greg Hambeli \#2', (16) 'Hope', (17) 'Hybrid Selloum', (18) 'Imperial Green’, (19) 'Imperial Red', (20) 'Octopus', (21) 'Panda', (22) 'Pertusum', (23) 'Pinnatifidum', (24) 'Prince of Orange', (25) 'Red Bristle', (26) 'Royal Queen', (27) 'Rudolph', (28) 'Sawtooth', (29) 'Showboat', (30) 'Tahiti Green', (S) space, (31) Anthurium control 'Red Hot', (32) Spathiphyllum control '64760', (33) Philodendron control 'Moonlight', (34) Dieffenbachia control 'Compacta', (35) Alocasia control 'Amazonica', (36) Aglaonema control 'Treubii', (S) space, and (M) size markers.

Table 2. AFLP primer combinations, primer sequences, total number of fragments generated by each primer set, number of polymorphic fragments detected, and percentages of polymorphic fragments used in the study of Philodendron cultivars.

\begin{tabular}{lccc}
\hline Primer & $\begin{array}{c}\text { Total no. of } \\
\text { fragments }\end{array}$ & $\begin{array}{c}\text { No. of polymorphic } \\
\text { fragments }\end{array}$ & $\begin{array}{c}\text { Polymorphic } \\
\text { fragments (\%) }\end{array}$ \\
\hline IRD700 E+TC/M+CAA & 106 & 70 & 60.0 \\
IRD800 E+AA/M+CAA & 96 & 68 & 70.8 \\
IRD700 E+TC/M+CAT & 106 & 68 & 64.2 \\
IRD800 E+AA/M+CAT & 130 & 75 & 57.7 \\
IRD700 E+GG/M+CAA & 110 & 72 & 65.5 \\
IRD800 E+CC/M+CAA & 116 & 71 & 61.2 \\
Total & 664 & 424 & 63.9 \\
Average & 110.7 & 70.7 & 63.9 \\
\hline
\end{tabular}




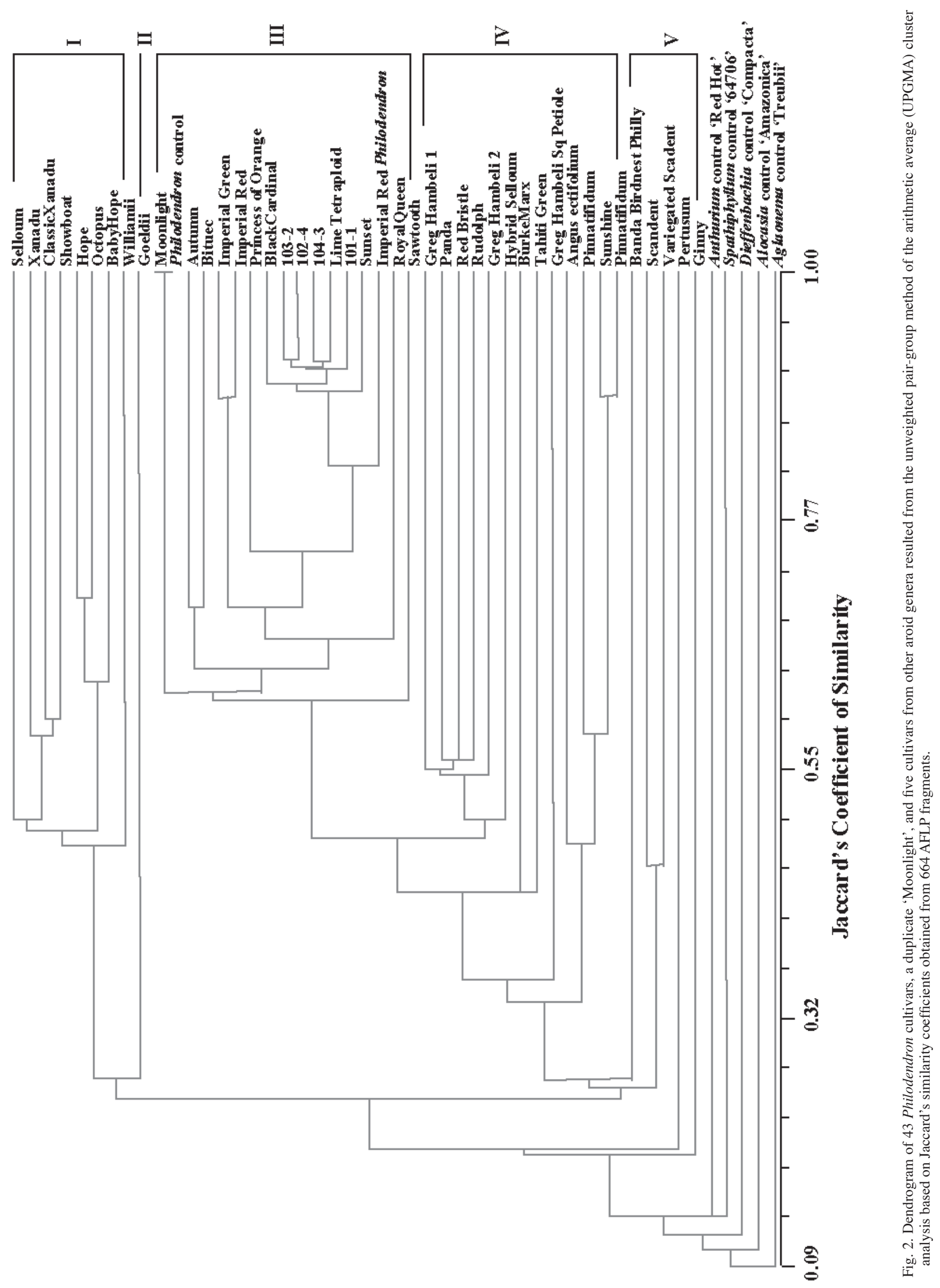


for 'Williamsii', which belongs to P. williamsii. However, Jaccard's similarity coefficients among the $P$. bipinnatifidum cultivars ranged from 0.49 to 0.7 , suggesting that $P$. bipinnatifidum might be rather heterozygous genetically. Similarly, 'Baby Hope', a somaclonal variant of 'Hope', shares a Jaccard's similarity coefficient of 0.63 with its parent 'Hope'. Jaccard's similarity coefficient between $P$. bipinnatifidum and $P$. williamsii, however, is only 0.48 .

There is only one cultivar 'Goeldii' in cluster II. This cultivar belongs to $P$. goeldii G. Barroso, a species native to French Guyana and maybe other tropical American regions. 'Goeldii' is a unique appearing species whose stem is erect or hanging, sometimes tortuous (Mayo, 1991). Leaf blades are reniform in outline and pedately compound (Croat, 1997) or schefflera-shaped leaves on upright petioles growing from the center of the plant.

Cluster III contains 16 cultivars and most of them are self-heading hybrids developed by R.H. McColley at Bamboo Nursery in Apopka, Fla. 'Moonlight' is a hybrid with faintly yellow, ovate leaves. 'Autumn' has orange and bronze leaves in a rosette form. 'Bituec' may be related to 'Autumn'. Both 'Imperial Green' (U.S. plant patent No. 6,086) and 'Imperial Red' (U.S. plant patent No. 6,337) were selected by Paul DeCoster in Mello, Belgium, from seedlings of McColley's hybrids. During the 1960s, McColley made hundreds of crosses using more than 15 species as parents in all possible combinations and obtained 1,000,000 hybrid seeds (McColley and Miller, 1965). Not all hybrid seedlings were evaluated by McColley, and parental information or pedigrees of some commercial hybrids such as 'Moonlight', 'Autumn', 'Bituec', 'Imperial Green', and 'Imperial Red' were not documented. 'Prince of Orange' (U.S. plant patent No. 6,797) was selected from several crosses involving five parents: P. domesticum (stem climbing and with bright green leaves), P. erubescens (stem climbing and with purple to red leaves), $P$. wendlandii (stem erect), $P$. imbe Endl. (stem climbing and with purple to red leaves), and $P$. cannifolium Kunth (stem prostrate). 'Black Cardinal' is a hybrid developed from a series of crosses involved $P$. wendlandii, $P$. domesticum, P. erubescens, P. imbe, P. fragrantissimum (Hook) Kunth (stem climbing), and an unnamed species and was patented as U.S. plant patent No. 5,355. '103-2' was selected from a cross between 'Moonlight' and 'Prince of Orange'. '102-4' is a hybrid of 'Emerald Princess' and 'Moonlight'. The origin of ' $104-3$ ' is unknown. 'Lime Tetraploid' is a tetraploidy Surath Vano. '101-1' is a hybrid selected from a cross between 'Prince of Orange' and 'Emerald Prince'. Parental information of 'Sunset' is not available. 'Imperial Red Philodendron', collected from the UCRBG, is apparently different from the 'Imperial Red' collected from Florida as their Jaccard's similarity coefficient is only 0.66. 'Royal Queen' is a hybrid with blood-red stem and petioles; medium-sized ovate leaves, bronze when young, and later glossy rich green. The origin of 'Sawtooth' is not documented.

There are 13 cultivars in cluster IV, and all have semi-vining growth style. The origin of 'Greg Hambeli 1' is unknown. 'Panda' is a P. bipennifolium Schott (syn. P.panduraeforme Kunth) or called fiddleleaf philodendron or horsehead philodendron. This species is a sparsely branched semi climber and native to Southeastern Brazil (Huxley, 1994). 'Red Bristle' may be related to P. pedatum (Hook) Kunth (syn. P. laciniatum Engl.). It may originate from southern Venezuela to southeastern Brazil with a population in northern Colombia (Bown, 2000). Background information of 'Rudolph' is unknown. 'Greg Hambeli 2' may be a relative of 'Greg Hambeli 1'. Again, its origin is unclear. 'Hybrid Selloum' could be a mislabeled plant as its Jaccard's similarity coefficient with the 'Selloum' related cultivars in cluster I is only 0.25. Cultivar
Burke Marx has light green and ovate-oblong leaves. It may be a cultivar of $P$. imbe. The background information of 'Tahiti Green' is not available. Information regarding 'Greg Hambeli square petiole is unknown. 'Angus Ectifolium' could actually be a $P$. angustisectum Engl., a moderate-sized semi climber. Leaves are ovate in outline but deeply pinnatifid looking like palm blades. This species is native to Colombia. There are two 'Pinnatifidum', one collected from central Florida and the other collected from the UCRBG. Both are P. pinnatifidum (Jacq.) Schott., a species originates from Brazil, but their Jaccard's similarity coefficient is only 0.58 . The background of 'Sunshine' is unclear; its close association with the 'Pinnatifidum' may indicate that the two are closely related as the Jaccard's similarity coefficient between the two is 0.79 .

Cluster V has five cultivars. The background of cultivar Banda Birdnest Philodendron is unknown. Both 'Scandent' and 'Variegated Scandent' are P. scandens, or commonly referred to as heartleaf philodendron. This species is native to Mexico, the West Indies, and southeastern Brazil. Heartleaf philodendron is a fast growing, slender climber with pendent terminal stems. It used to be the dominant plant in the foliage plant industry with its highest wholesale value of a single species from the 1950s to 1960s. Morphologically, the only difference between the two 'Scandent' cultivars is that one has solid green leaves and the other has variegated leaves. The solid green 'Scandent' cultivar has been cultivated for more than two centuries since its first introduction in 1793 (Bown, 2000). This plant is propagated through eye cutting because it has never produced seeds in cultivation and not been propagated by tissue culture. The variegated cultivar is a recent discovered sport from the solid green cultivar. However, their Jaccard's similarity coefficient is only 0.46 ; such distant relationship may suggest that somatic mutations could have been accumulated in 'Scandent'. 'Pertusum' is a P. pertusum Kunth $\&$ Bouche and it has been called split-leaf philodendron in the foliage plant industry. However, this plant may actually be a Monstera deliciosa Liebm., another genus of the family Araceae, as its Jaccard's similarity with other philodendrons is only 0.2 or lower. 'Ginny' is a cultivar located in cluster $\mathrm{V}$ with split leaves as well. It may, like 'Pertusum', not belong to Philodendron since its Jaccard's similarity coefficient is only 0.19 or less comparing with other Philodendron cultivars.

We included five other genera of Araceae (Aglaonema, Anthurium, Alocasia, Dieffenbachia, and Spathiphyllum) in this study. These five generic accessions were properly positioned outside the Philodendron clusters and the genetic similarities among these five genera are $\leq 0.14$. They shared a genetic similarity of no higher than 0.10 with any Philodendron samples.

Five GROUPS OF CULTIVATED PHILODENDRONS AND THEIR IMPLiCATions With BREeding. The PCA clearly separated the 43 Philodendron cultivars into five clusters (Fig. 3). If one thinks that the UPGMA analysis reflected in the dendrogram (Fig. 2) only loosely clustered cultivars in clusters IV and V, the PCA confirms the classification of the cultivated philodendrons into five groups. Cultivars in the cluster I are all arborescent types. 'Goeldii' is the only cultivar in cluster II, which has erect or hanging, sometimes tortuous stem and schefflera-shaped leaves. Cultivars in cluster III are all selfing-heading and predominantly derived from McColley's breeding program. Semi-vining cultivars are positioned in cluster IV, and the true vining type is situated in cluster $\mathrm{V}$. The true vining type of philodendrons in cluster $\mathrm{V}$ are genetically distant from other philodendrons and relatively closer to other aroid genera (Figs. 2 and 3). Comparing to the traditional 


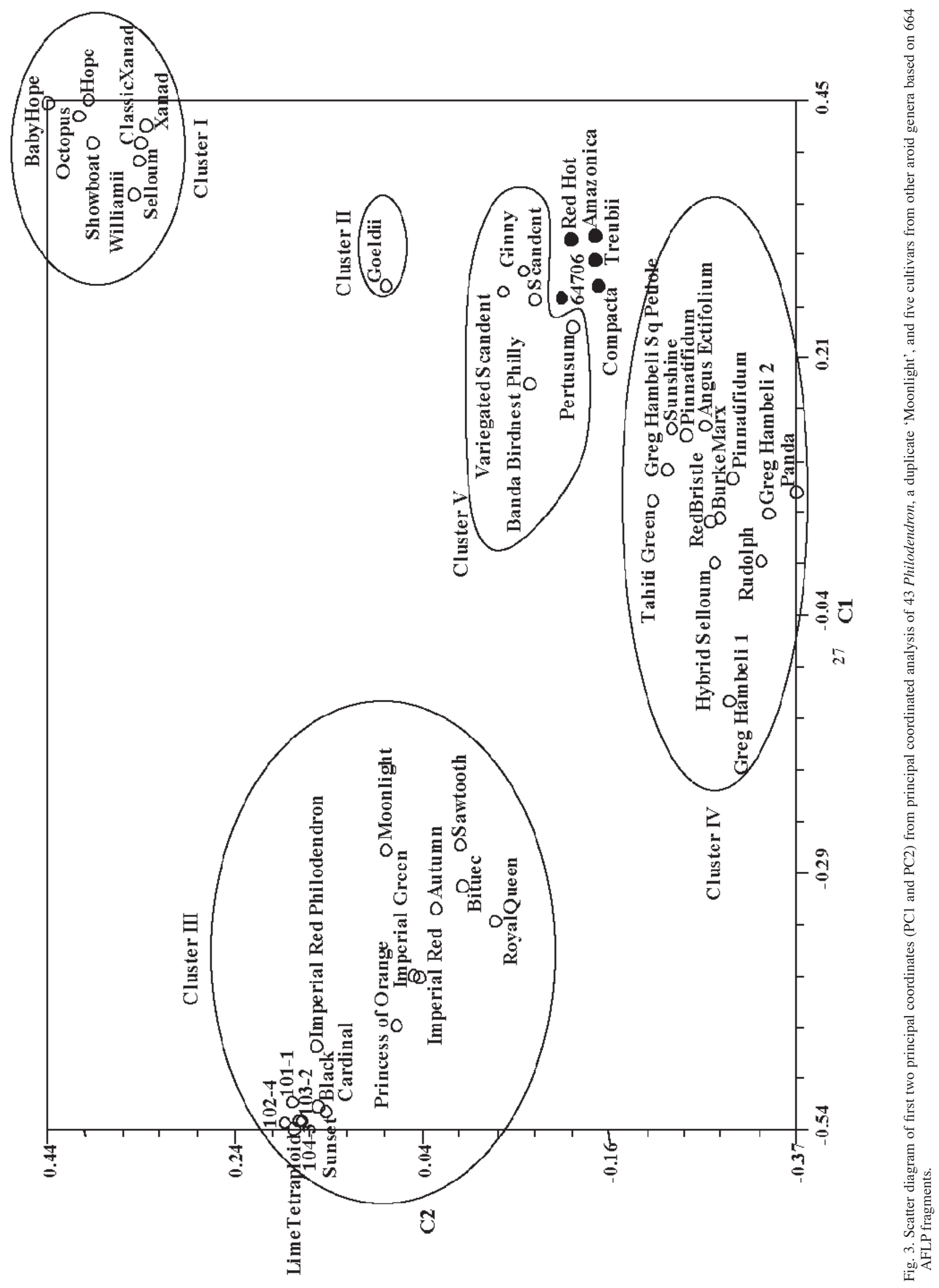


three groups, it appears that McColley and Miller (1965) did not take 'Goeldii' and semi-vining type into their considerations. Our study showed that semi-vining type should be an independent group, which is based on the following considerations: 1) semivining plants were genetically distant from the true vining types (Jaccard's similarity of 0.26 ); 2) this group of plants has large lanceolate blades, varying in leaf colors and thickness, and strong stems; and, most importantly, 3) semi-vining plants were primary materials used for crossing with self-heading species such as $P$. wendlandii by which interspecific hybrids with various colors were produced. Therefore, we postulate that some species from the semi-vining group may actually be bridge species that can be used to cross with either arborescent or even some true vining type to create new interspecific hybrids.

Additionally, since philodendrons are open-pollinated and propagated mainly by vegetative means, some species may be extremely heterozygous. For example, 'Hope', selected from selfing of 'Selloum', shares a Jaccard's similarity coefficient of only 0.5 with its parent. Such large genetic difference may suggest that new cultivars can be directly developed through selfing of highly heterozygous parents. Additionally, 'Baby Hope' was selected from somaclonal variants of 'Hope', Jaccard's similarity coefficient between the two is 0.62 . Sport of 'Variegated Scanden' shares a Jaccard's coefficient of 0.46 with its parent 'Scanden'. These rather distant relationships between somaclonal variants or sport with their parents indicate that new cultivars can also be developed from selection of somaclonal variants or sports of philodendrons.

Furthermore, this study reveals that cultivars with the same names are genetically different. For example, 'Pinnatifidum' collected from central Florida has a Jaccard similarity coefficient of 0.58 with the same named cultivar collected from UCRBG. It might be possible that both belong to $P$. pinnatifidum but are different cultivars. 'Imperial Red' cultivated in central Florida share a Jaccard's coefficient of 0.66 with 'Imperial Red Philodendron' collected from UCRBG. These two cultivars might come from R.H. McColley's breeding program as they are morphologically similar. Apart from different cultivars being given the same names, mislabeling cultivars also occurs. 'Hybrid Selloum' resembles little with $P$. bipinnatifidum 'Selloum' both morphologically and genetically. The mislabel could be a problem that affect philodendron germplasm conservation and utilization as valuable genetic resources could be lost due to the mislabeled same names. Molecular marker technologies, such as AFLP, show great promise for cultivar identifications.

Using the AFLP technique, we were able to position 43 Philodendron cultivars into five clusters based on the polymorphism generated by six AFLP primer sets as well as their growth habits. We propose the five clusters are five groups (arborescent, goeldii, self-heading, semi-vining, and vining types) of cultivated ornamental foliage philodendrons. Plants from the semi-vining type may be able to cross with species in the other groups to create new interspecific hybrids. Additionally, the AFLP analysis suggests that 'Pertusum' and 'Ginny' may not belong to the genus Philodendron. Nevertheless, the AFLP profiles and the clusters identified from this study can be used as reference for future interspecific hybrid development. The genetic similarity among cultivars established could help in Philodendron germplasm identification, preservation, and new cultivar development.

\section{Literature Cited}

Aggarwal, R.K., V.V. Shenoy, J. Ramadevi, R. Rajkumar, and L. Singh. 2002. Molecular characterization of some Indian Basmati and other elite rice genotypes using fluorescent-AFLP. Theor. Appl. Genet. 105:680-690.

Bald, J.G. 1951. Gladiolus diseases. A progress report on current research compiled from discussions at eighth annual convention, North American Gladiolus Council, Cleveland, Ohio. 15-18 Jan.

Bown, D. 2000. Aroids: Plants of the arum family. 2nd ed. Timber Press, Portland, Ore.

Chen, J., P.S. Devanand, D.J. Norman, R.J. Henny, and C.T. Chao. 2004a. Genetic relationships of Aglaonema species and cultivars inferred from AFLP markers. Ann. Bot. 93:157-166.

Chen, J., R.J. Henny, and D.B. McConnell. 2002. Development of new foliage plant cultivars, p. 466-472. In: J. Janick and A. Whipkey (eds.). Trends in new crops and new uses. ASHS Press, Alexandria, Va.

Chen, J., R.J. Henny, D.J. Norman, P.S. Devanand, and C.T. Chao. 2004b. Analysis of genetic relatedness of Dieffenbachia cultivars using AFLP markers. J. Amer. Soc. Hort. Sci. 129:81-87.

Croat, T.B. 1997. A revision of Philodendron subgenus Philodendron (Araceae) of Central America. Missouri Botanical Garden Press, St. Louis.

Grayum, M.H. 1996. Revision of Philodendron subgenus Pteromischum (Araceae) for Pacific and Caribbean tropical America. Syst. Bot. Monogr. 47:1-233.

Griffith, L.P. 1998. Tropical foliage plants: A grower's guide. Ball Pub., Batavia, Ill.

Henny, R.J. and J. Chen. 2003. Foliage plant cultivar development. Plant Breed. Rev. 23:245-290.

Huxley, A. 1994. The New royal horticultural society dictionary of gardening. Macmillan, London.

Liberty Hyde Bailey Hortorum. 1976. Hortus III. Macmillan, New York.

Mayo, S.J. 1991. A revision of Philodendron subgenus Meconostigma (Areacea). Kew Bul. 46:601-681.

Mayo, S.J., J. Bogner, and P.C. Boyce. 1997. The genera of Araceae. The Royal Botanic Gardens, Kew, London.

McColley, R.H. and N.H. Miller. 1965. Philodendron improvement through hybridization. Proc. Fla. State Hort. Soc. 78:409-415.

McConnell, D.B., R.W. Henley, and C.B. Kelly. 1989. Commercial foliage plants: Twenty years of changes. Proc. Fla. State Hort. Soc. 102:297-303.

Muller, U.G. and L.L. Wolfenbarger. 1999. AFLP genotyping and fingerprinting. TIEE 14:389-394.

Myburg, A.A., D. O'Malley, R.R. Sederoff, and R. Whetten. 2000. High-throughput multiplexed AFLP analysis of interspecific hybrids of Eucalyptus trees species. Plant and Animal Genome VIII Conf., San Diego.

Norris, C.A. 1987. The business of breeding at bamboo nurseries. Grower Talks (January):60-62.

Rohlf, F.J. 2000. NTSYSpc, numerical taxonomy and multivariate analysis system, version 2.1 user guide. Exeter Software, Setauket, N.Y.

Sneath, P.H.A. and R.R. Sokal. 1973. Numerical taxonomy: The principles and practice of numerical classification. W.H. Freeman and Co., San Francisco.

Vos, P.R., M. Hogers, M. Bleeker, T. van de Lee Reijans, M. Hornes, A. Fritjers, J. Pot, J. Peleman, M. Kuiper, and M. Zabeau. 1995. AFLP: A new concept for DNA fingerprinting. Nucleic Acids Res. 23:4407-4414.

Wilfret, G.J. and T.J. Sheehan. 1981. Development of new foliage plant cultivars, p. 126-136. In: J.N. Joiner (ed.). Foliage plant production. Prentice-Hall, Englewood Cliffs, N.J. 